\title{
Piagam Jakarta dan Implikasinya Terhadap Konstruksi Pemikiran Islamisme Indonesia Kontemporer
}

\section{Rendy Andiwilaga}

Ilmu Pemerintahan, Universitas Bale Bandung rendyadiwilaga@gmail.com

\begin{abstract}
Abstrak
Tulisan ini hendak menggali historisitas Piagam Jakarta sebagai gentlemen agreement para pendiri bangsa hingga implikasinya terhadap bentuk gerakan-gerakan islamisme kontemporer yang saat ini laris dalam pemasaran dakwah serta memiliki kekuatan yang cukup menentukan dalam perumusan kebijakan politis maupun hukum. Representasi gerakan yang tertuang dalam gerakan 212 atau GNPF-Ulama menjadi tanda bahwa kelompok Islam saat ini mulai menunjukkan eksistensinya kembali pasca pemberangusan yang dilakukan rezim Orde Baru sebelumnya. Pada akhirnya tulisan ini menjelaskan bahwa Piagam Jakarta dan gerakan islamisme kontemporer memiliki mimpi yang sama tentang formalisasi Islam dimana formalisasi Islam tersebut merupakan pengaruh langsung untuk saat ini, dari adanya upaya pengesahan Piagam Jakarta. Hanya terdapat perbedaan kontras dalam hal perjuangan serta bentuk gerakan dimana para pejuang Piagam Jakarta yang terhitung hingga tumbangnya Masyumi, cenderung memiliki bentuk gerakan yang terkonsep secara ideologis dan tidak mengikat. Sedangkan kelompok Islamisme kontemporer cenderung tidak memiliki wujud gerakan yang pasti bahkan berbeda-beda satu sama lain.
\end{abstract}

Kata Kunci: Piagam Jakarta, Kelompok Islam, Islamisme

\section{Abstract}

This paper seeks to explore the historicity of the Jakarta Charter as a gentlemen's agreement for the founders of the nation to its implications for the forms of contemporary Islamism movements that are currently in demand in the marketing of Da'wah and have sufficient decisive power in the formulation of political and legal policies. Representation of the movements contained in the 212 or GNPF-Ulama movement is a sign that Islamic groups are now beginning to show their existence again after the suppression carried out by the previous New Order regime. In the end, this paper explains that the Jakarta Charter and the contemporary Islamism movement have the same dream about the formalization of Islam, 
where the formalization of Islam is a direct influence for the time being, from the ratification of the Jakarta Charter. There are only contrasts in terms of the struggle and form of the movement where Jakarta Charter fighters who counted until the fall of Masyumi, tend to have a form of movement that is ideologically conceptualized and not binding. Whereas contemporary Islamism groups tend not to have a definite form of movement even varying from one another.

Keywords: Jakarta Charter, Islamic Groups, Islamism

\section{Pendahuluan}

Formalisasi Islam sebagai dasar negara seperti yang diperjuangkan oleh Hizbut Tahrir Indonesia dewasa ini, serta organisasi-organisasi lainnya yang menghendaki adanya aturan Syariah yang memayungi seluruh aspek kehidupan masyarakat termasuk dalam ranah privat masyarakat, pada dasarnya bukanlah upaya baru dalam perjalanan panjang pendewasaan republik. Upaya tersebut berkali-kali disuarakan, baik dengan cara-cara konstitusional seperti halnya yang dilakukan oleh anggota Majelis Konstituante medio 1957-1959, hingga cara-cara dialektis seperti halnya diskusi-diskusi di kampus-kampus besar yang dilakukan oleh Dewan Dakwah Islam Indonesia (DDII, cikal bakal KAMMI dan PKS). Adapun cara yang lebih 'radikal', pernah dilakukan oleh S.M Kartosoewirjo dengan DI/TII nya, dan saat ini, berkembang wacana pemikiran Islamic State of Iraq $\mathcal{E}$ Sjam (ISIS) serta pendahulu-pendahulu lainnya seperti halnya Al-Qaeda (Firdausi, 2018).

Namun jauh sebelum peristiwa-peristiwa tersebut, pada masa kelahirannya, Indonesia pernah berada pada persimpangan jalan yang cukup menentukan jejak langkah ke depan sebagai negara. Pada sidang BPUPK sebagai wadah para tokoh bangsa saat itu guna mengemukakan dasar negara, wacana tentang Islam sebagai dasar negara sudah mulai muncul, tepatnya saat perumusan Piagam Jakarta yang oleh kelompok Islam diusulkan dengan penuh perjuangan. Adapun nyawa dari Piagam Jakarta sendiri ialah rumusan Pancasila sila pertama yang berbunyi: "Ketuhanan, dengan Kewajiban Menjalankan Syariat Islam bagi Pemeluknya", atau kemudian dikenal dengan istilah "tujuh kata".

Piagam Jakarta menjadi penanda bahwa Islam merupakan kekuatan penentu dalam dinamika politik bangsa, khususnya pada saat pendirian negara hingga tumbangnya pemerintahan Soekarno di tangan Soeharto. Hal ini cukup beralasan mengingat pasca urungnya Piagam Jakarta disahkan, berkali-kali kekuatan Islam mampu memantik api terkait isu pengesahan kembali rumusan tersebut. Di sisi lain, dua kekuatan besar Islam pada saat itu, Partai Nahdhatul Ulama Indonesia (PNUI) dan Partai Masyumi, masuk dalam 4 besar partai pemenang pemilu pada tahun 1955 disamping kemenangan PNI dan kejutan yang dihadirkan PKI sebagai peringkat ke 4. Dari sini saja, kita bisa simpulkan bahwa kelompok Islam bukanlah kekuatan musiman atau kelompok "kemarin sore" yang kekuatannya tidak perlu 
diperhitungkan. Kelompok Islam nyatanya menjelma menjadi kekuatan besar dan kekuatan penentu selama berkali-kali pada masa pertumbuhan republik.

Redupnya eksistensi kelompok Islam diawali dengan pelarangan Masyumi akibat dugaan keterlibatannya dalam pemberontakan PRRI/Permesta yang melibatkan tokoh-tokoh besar Masyumi seperti M. Natsir dan Sjafroedin Prawiranegara. Kebangkitan rezim Soeharto semakin memperparah eksistensi kelompok Islam karena Kelompok Islam hanya diperbolehkan menjalankan aktivitas politik pada satu wadah, yakni Partai Persatuan Pembangunan (PPP) mulai pemilu tahun 1977. Peristiwa Tanjung Priok menjadi salah satu indikator bahwa Soeharto sama sekali tidak bersahabat dengan kelompok Islam. Kelompok Islam di masa Soeharto benar-benar selesai setelah NU memutuskan kembali ke khittah NU 1926 pada muktamar NU tahun 1983 di Situbondo. Walaupun secara diam-diam, DDII pimpinan Natsir gencar melakukan gerilya dakwah di masjid kampus-kampus besar. Ditambah, melalui masjid besar kampus pula, Hizbut Tahrir mulai masuk pada awal 1980-an (Adiwilaga, 2017: 1-9).

Formalisasi Islam sebagai dasar negara, yang tertuang dalam syariatisme atau khilafatisme, dewasa ini mulai bergejolak kembali menjadi sebuah diskursus yang tak lagi tabu diperbincangkan. Reformasi dengan segala keterbukaan dan kebebasannya, memberikan karpet merah bagi diskursus-diskursus ideologi baru untuk memamerkan kemolekan-kemolekan praksisnya terkecuali marxismekomunisme karena masih dilarang secara konstitusional oleh Tap MPRS No. XXV/1966 (belum dicabut). Tumbangnya Soeharto memberikan keleluasaan bagi Kesatuan Aksi Mahasiswa Muslim Indonesia (KAMMI) sebagai representasi politis DDII untuk kemudian mendirikan Partai Keadilan yang selanjutnya kita kenal sebagai Partai Keadilan Sejahtera (PKS) sebagai partai yang secara konstitusional paling aktif dalam kegiatan-kegiatan keislaman baik kegiatan formal maupun protes-protes khusus seperti halnya aksi 411 dan 212.

Pesatnya akses informasi juga mempersilahkan konsep islam transnasional masuk ke bumi nusantara. Selain keterwakilan PKS di parlemen dengan pemikiranpemikiran yang terinspirasi dari kejayaan AKP pimpinan Erdogan di Turki dan Ikhwanul Muslimin di Mesir, pemikiran-pemikiran baru baik pemikiran dari arus utama maupun arus militan mulai masuk, termasuk di dalamnya pemikiranpemikiran salafi-wahabi yang saat ini semakin berkembang atas nama "pemurnian Islam". Sayangnya, dalam tataran grassroot, pemikiran-pemikiran inilah yang kemudian cukup berpengaruh, khususnya di kalangan pemuda serta generasi boomer yang tidak terbiasa dengan kegiatan menyaring informasi dan cenderung menelan mentah setiap informasi yang diterima.

\section{Kerangka Teori}

Piagam Jakarta, atau dalam istilah Sukiman disebut sebagai gentlemen Agreement, pada dasarnya merupakan sebuah simbol akan adanya upaya 
"penagihan apresiasi" atau pengakuan dari golongan Islam, terkait kontribusi besarnya dalam mengisi kendi-kendi kemerdekaan melalui perjuangan, ditambah dengan mayoritas masyarakat Indonesia yang sebagian besar memeluk agama Islam. Namun pada akhirnya, Piagam Jakarta urung disahkan setelah melewati proses kompromi panjang antara para perumus dasar negara di sidang-sidang persiapan kemerdekaan.

Di antara kalangan muslim dalam BPUPKI, Ki Bagus Hadikusumo ialah orang paling bersemangat yang menginginkan kalimat "Ketuhanan dengan kewajiban menjalankan syariat Islam bagi pemeluk-pemeluknya" tercantum dalam pembukaan Undang-undang Dasar. Ki Bagus Hadikusumo pernah memaparkan pentingnya Islam sebagai dasar negara Indonesia pada sidang BPUPKI tanggal 28 Mei 1945. Namun semua paparannya selalu mendapat bantahan dari anggota lain yang menentang negara Islam. Sidang tampaknya bakal menemui kebuntuan. Hingga akhirnya Ki Bagus berdoa di depan para hadirin:

“Ya Allah, berikan kami petunjuk ke jalan yang benar, yaitu jalan yang telah Engkau beri nikmat dan bukan jalan orang-orang yang Engkau murkai, bukan pula jalan orang-orang yang sesat (Matanasi, 2019)."

Prinsip kompromi Piagam Jakarta sesungguhnya terletak pada bagaimana Islam tidak menjadi dasar negara, tetapi umat Islam wajib menjalankan syariat Islam yang akan diatur dalam konstitusi. Penjelasan Kasman Singodimedjo juga menegaskan bahwa tujuh kata Piagam Jakarta sangat fleksibel. Menurutnya, golongan nonmuslim tidak akan diwajibkan untuk menjalankan syariat Islam, hanya terbatas kepada umat Islam. Toleransi Islam menjamin golongan nonmuslim untuk mengamalkan ibadah sesuai keyakinannya. Seperti dilakukan Nabi Muhammad pada zamannya (Singodimedjo, 1982). Namun, pendapat tersebut tetap sulit diterima oleh golongan diluar golongan Islam, karena menurut mereka, sila tersebut berpotensi melahirkan diskriminasi di tataran grassroot, ditambah, golongan nonmuslim juga merasa bahwa kontribusi mereka dalam merebut kemerdekaan juga tak kalah besar. Hatta, bahkan menegaskan dalam memoir nya bahwa "tercantumnya ketetapan seperti itu di dalam suatu dasar yang menjadi pokok Undang-Undang Dasar berarti mengadakan diskriminasi terhadap mereka (yang) golongan minoritas."

Pertentangan yang terus menerus tersebut bukanlah tanpa sebab. Kita perlu komprehensif dengan menggali lebih dalam latar belakang pemikiran dan lingkungan para tokoh perumus dasar negara tersebut. Seperti contoh (Latif, 2012: 78-79), mereka yang menyuarakan ide negara Islam, pada umumnya berasal dari lingkungan pendidikan Islam yang kurang bersentuhan dengan diskursus negara modern dan nasionalisme kewargaan. Adapun mereka yang menganjurkan pemisahan antara negara dan agama, pada umumnya berasal dari lingkungan pendidikan barat yang sangat terpengaruh oleh modernisme Eropa, pada masa ketika sekularisme bergema kuat, sehingga kurang memahami alam keagamaan (terlebih khususnya Islam). 
Dari pertentangan pemikiran tersebut, menghasilkan sebuah butir bernama Piagam Jakarta yang salah satunya memiliki kandungan kalimat: "Ketuhanan dengan kewajiban menjalankan syariat Islam bagi pemeluk-pemeluknya." Di mana sila tersebut menjadi sila kontroversial yang mengundang banyak ketidaksetujuan dari kelompok Indonesia Timur yang sebagian besar merupakan kelompok nonmuslim. Bahkan, kelompok Indonesia Timur mengancam tidak ikut serta dalam menjunjung tinggi bangsa dan negara yang satu ke depannya, dimana hal tersebut, jelas dapat memberikan angin segar bagi kolonialisasi Belanda jilid berikutnya. Di PPKI, anggota nonmuslim diwakili oleh Johannes Latuharhary, orang Ambon; Sam Ratulangi, orang Minahasa; dan I.G. Ketoet Poedja, orang Bali.

\section{Metode Peneltitian}

Dalam penelitian ini, peneliti menggunakan metode kualitatif dimana pada dasarnya penelitian dengan pendekatan fenomenologi hermeneutik bertujuan untuk menyediakan pemahaman mendalam tentang kasus dan mengembangkan deskripsi serta analisis terhadap kasus tersebut (Hikmawan, 2017). Data dikumpulkan baik secara literature terdahulu juga data-data yang ada baik dari sumber utama maupun sumber rujukan kedua. Dalam Pendekatan Fenomenologi hermeneutik, data dari literature terdahulu dihunakan sebagai sumber untuk di interpretasi dan dimaknai, mengungkapkan data-data terdahulu tidak hanya menjadi sebuah sumber peneliti dalam mempertimbangkan dalam hasil analisis, lebih jauh pendekatan fenomenologi hermenutik juga membawa peneliti dalam memahami kondisi pada saat itu dan menyingkapkan makna yang terjadi saat itu yang dapat berimplikasi kepada keputusan-keputusan politik yang diambil. Dari semua itulah sebagai sebuah pendekatan, fenomenologi hermeneutik memiliki banyak keunggulan dalam memahami studi literature.

\section{Hasil dan Diskusi}

\section{Menyelami Lebih Dalam Konflik Piagam Jakarta}

Pada 10 Juli 1945, Sukarno menyampaikan rumusan Piagam Jakarta dalam sidang BPUPKI. Saat itu ia bersungguh-sungguh meyakinkan anggota sidang untuk menerima Piagam Jakarta sebagai rumusan terbaik pembukaan UUD 1945. Dalam kasus ini, bisa dilihat bahwa Soekarno pada awalnya menyetujui letak dasar Piagam Jakarta. Soekarno bahkan kokoh mempertahankan keyakinannya terkait Piagam Jakarta, khususnya sila kesatu, saat menerima kritik dari tokoh-tokoh sidang yang tidak menyepakati dasar tersebut. Salah satu tokoh yang menolak pengesahan Piagam Jakarta ialah Johannes Latuharhary, wakil dari Ambon dalam sidang BPUPK. Soekarno saat Latuharhary menyampaikan keberatannya, bahkan membantah kekhawatiran Latuharhary bahwa kewajiban menjalankan syariat Islam bagi pemeluknya akan menciptakan benturan dengan hukum adat di masyarakat. per tanggal 10 Juli hingga 16 Juli 1945, Piagam Jakarta akhirnya disahkan melalui 
sidang marathon, sebagai Mukadimah UUD 1945. Para tokoh saat itu kemudian sepakat untuk mempertahankan kalimat: "Ketuhanan Dengan Kewajiban Menjalankan Syariat Islam bagi Pemeluk-Pemeluknya," dan berlaku, sebelum kemudian, sehari setelah kemerdekaan, Hatta melakukan manuver penting lainnya.

Malam hari setelah proklamasi disuarakan di jalan Pegangsaan Timur No. 56, pada malamnya, tanggal 17 Agustus 1945 Bung Hatta menerima kunjungan seorang perwira angkatan laut Jepang untuk menyampaikan keberatan dari penduduk Indonesia timur yang tidak beragama Islam mengenai dimuatnya Piagam Jakarta pada Mukaddimah UUD 1945. Mereka mengancam akan memisahkan diri dari NKRI jika tujuh kata dalam pembukaan konstitusi negara tersebut tidak dihilangkan (Akbar, 2017). Berangkat dari desakan tersebut, Hatta akhirnya menemui perwakilan golongan Islam serta membujuk untuk menyetujui penghapusan "tujuh kata" seperti dalam kesepakatan dan keputusan sebelumnya. Di antara tokoh yang ditemui dan dibujuk Hatta antara lain kepada Ki Bagus Hadikusumo, dan Teuku Muh. Hassan. Sedangkan KH. Wahid Hasyim tidak dapat ditemui karena sedang pulang ke Jawa Timur. Muh. Hatta berusaha meyakinkan tokoh-tokoh Islam atas nama persatuan dan kesatuan bangsa.

Satu per satu, tokoh-tokoh Islam tersebut melunak hingga menyisakan satu penantang tergigih, yakni Ketua Muhammadiyah pada saat itu, Ki Bagus Hadikusumo. Rapat non formal sebelum dimulainya sidang PPKI pada tanggal 18 Agustus 1945 tersebut pada dasarnya memberikan keterangan kepada tokoh-tokoh Islam tentang kerugian besar yang akan datang saat kelompok Indonesia Timur menarik diri dari NKRI, kerugian tersebut dapat berupa kedatangan kolonialisme Belanda kembali disertai ketakutan akan lemahnya kekuatan diplomasi Indonesia jika Indonesia bagian Timur tidak bergabung.

Melihat kondisi tersebut, Soekarno memainkan peran penting dengan meminta Kasman Singodimedjo menjadi anggota tambahan PPKI bersama Wiranata Kusumah, Ki Hadjar Dewantara, Sayuti Melik, Iwa Kusumasumantri, dan Ahmad Subarjo. Hingga pada akhirnya, jumlah anggota PPKI menjadi 27 orang dari semula 21 orang. Dalam posisi tersebut, Soekarno sebagai ketua PPKI, kemudian menugaskan Kasman Singodimedjo agar mampu membujuk Ki Bagus Hadikusumo, atas dasar pertimbangan kedekatan Ki Bagus dengan Kasman itu sendiri. Dengan bahasa Jawa halus, Kasman membujuk Ki Bagus. Ia menerangkan dalam UndangUndang Dasar yang akan disahkan hari itu terdapat satu pasal yang menyatakan bahwa enam bulan setelah Majelis Permusyawaratan Rakyat dibentuk, akan dilakukan sidang penyempurnaan Undang-Undang Dasar. Di saat itulah golongan Islam bisa kembali memperjuangkan isi Piagam Jakarta. Mendengar penjelasan Kasman, Ki Bagus akhirnya luluh. Ia setuju tujuh kata dalam Piagam Jakarta dihilangkan dalam sidang resmi PPKI (Akbar, 2017).

Selain itu, adik dari Tjokroaminoto, yakni Abikoesno Tjokrosoejoso, juga memainkan peranan penting dalam membujuk Ki Bagus Hadikusumo. Saat keputusan sidang deadlock, ada upaya untuk melakukan voting. Namun kemudian 
Abikoesno menilai bahwa voting tidak perlu karena, seperti kata Bung Karno, isi Piagam Jakarta, termasuk sila pertama, sudah merupakan hasil kompromi. Menurutnya:

“Kalau tiap-tiap dari kita harus, misalnya, dari golongan Islam harus menyatakan pendirian, tentu saja kita menyatakan, sebagaimana harapan Tuan (Ki Bagus) Hadikusumo... Tetapi kita sudah melakukan kompromi, sudah melakukan perdamaian (Anshari, 1997)."

Apa yang dikatakan Abikoesno kemudian mampu meluluhkan nurani Ki Bagus Hadikusumo sehingga beliau mau menerima keputusan bahwa dasar negara Indonesia adalah Pancasila (versi pengesahan PPKI). Namun dengan catatan, Ki Bagus menginginkan persoalan agama ditempatkan sebagai sila pertama. Dan akhirnya, Pancasila sila pertama diresmikan dengan bunyi: "Ketuhanan Yang Maha Esa". KH. Wahid Hasyim yang notabene tokoh perwakilan Islam dan Nahdlatul Ulama (NU), secara bijak dan arif mengusulkan agar frase yang menjadi titik sengketa antara kelompok nasionalis Islam dan nasionalis sekuler serta non-Muslim juga dicoret. Frase yang berbunyi "Ketuhanan dengan kewajiban menjalankan syariat Islam bagi pemeluknya" diubah menjadi "Ketuhanan Yang Maha Esa”.

Perubahan tersebut jelas berdampak sistemik dan berimplikasi terhadap perubahan batang tubuh UUD 1945. Dalam rapat resmi PPKI, yang dipimpin Soekarno, disepakati sejumlah hal seperti: mengubah kata "Mukaddimah" dalam pembukaan UUD 1945 menjadi "Pembukaan". Kemudian mencoret kalimat "beragama Islam" dalam Pasal 6 ayat 1 UUD 1945 dari semula berbunyi: "Presiden ialah orang Indonesia asli dan beragama Islam" menjadi "Presiden ialah orang Indonesia asli". Selanjutnya, Pasal 29 ayat 1 diubah dari "Negara berdasarkan atas Ketuhanan, dengan kewajiban menjalankan syariat Islam bagi pemelukpemeluknya" menjadi "Negara yang berdasarkan atas Ketuhanan yang Maha Esa (Akbar, 2017)."

Setelah rapat selama 15 menit dengan dinamika yang alot, tujuh kata dalam Piagam Jakarta itu pun dihapus. Alasan dominan: Republik Indonesia harus berdiri dengan menyertakan dan melibatkan kawasan Indonesia timur. "Perubahan yang disetujui lima orang tadi, sebelum rapat resmi, disetujui oleh sidang lengkap PPKI dengan suara bulat. Sesudah itu dipersoalkan Undang-undang Dasar yang seluruhnya, dengan mengadakan sedikit perubahan sana-sini yang tidak prinsipil," tulis Hatta, serta mengangkat Soekarno dan Mohammad Hatta sebagai presiden dan wakil presiden Republik Indonesia pertama. UUD 1945 yang telah disahkan oleh PPKI itu terdiri dari "pembukaan" dan "Batang Tubuh UUD” yang berisi 37 pasal, 1 aturan peralihan terdiri dari 4 pasal, 1 aturan tambahan terdiri dari 2 ayat.

\section{Upaya Formalisasi Islam Konstitusional Terakhir di Indonesia}

Pertentangan kolosal yang terjadi antara kelompok kebangsaan dan kelompok Islam dalam diskursus perumusan dasar negara, nyatanya tidak serta 
merta usai pasca pengesahan Pancasila dan UUD 1945 pada sidang PPKI terakhir. Ketidakpuasan kelompok Islam ditambah janji-janji dari kelompok kebangsaan yang menganggap bahwa Pancasila tanpa sila kewajiban menjalankan syariat Islam bersifat sementara, pada akhirnya menjaga bara api harapan terkait terwujudnya bangsa yang Syariah terus menyala.

Tak bisa ditampik bahwa salah satu hal yang meluluhkan Ki Bagus Hadikusumo yang bersikeras mengesahkan piagam Jakarta, adalah bujukanbujukan penting dari Kasman Singodimedjo dkk (atas dasar permintaan Soekarno) bahwa pembahasan mengenai Islam sebagai dasar negara dapat ditunda dan dibahas kembali di kemudian hari. Perlu diketahui bersama bahwa berdasarkan catatan sejarah, bujukan tersebut bukan hanya sekedar gombalan yang membuai, namun perlahan mulai didiskusikan dalam pidato-pidato maupun pertemuanpertemuan resmi, beberapa diantaranya yang akan dibahas yakni pertemuan majelis konstituante di era 1957-1959.

Dinamika sejarah yang cukup menyita perhatian pemerintah Soekarno, cukup mampu membabak belurkan pemerintahan saat itu, mulai dari diplomasi yang melelahkan dengan kerajaan Belanda, agresi militer I dan II yang juga dilakukan Belanda, lalu pemberontakan-pemberontakan lokal dari sahabat-sahabat masa muda Soekarno sendiri seperti Pemberontakan PKI di Madiun yang diinisiasi Musso, serta pemberontakan DI/TII yang diinisiasi oleh S.M. Kartosoewirjo, juga tak kalah berkontribusi dalam upaya pengeroyokan republik. Tak hanya itu, rongrongan merayap pihak luar dalam pemberontakan PRRI/Permesta juga cukup merepotkan pemerintah Indonesia pada saat itu. Tak hanya peristiwa-peristiwa tersebut, pergantian kabinet setiap tahunnya dalam sistem parlementer yang dianut republik, juga ikut berkontribusi dalam terkurasnya stamina Indonesia pada masa tersebut.

Kondisi politik yang kurang stabil, kemudian mendorong tokoh-tokoh penting yang saat sidang BPUPK dan PPKI bersikeras menegakkan Islam sebagai dasar negara, mulai kembali terusik untuk membahas nya kembali pada majelismajelis resmi. Namun, sebelum diskursus tersebut digulirkan, perlu dipahami bersama bahwa kelompok Islam telah membangun sebuah kutub kelompok yang disinyalir cukup kuat, yakni menguatnya peran dan pengaruh Partai Masyumi sebagai salah satu representasi kelompok Islam.

Masyumi yang sebelumnya bersama NU (setelahnya, NU keluar dari Masyumi dan resmi menjadi partai sendiri pada pemilu 1955), Muhammadiyah, serta organisasi Islam lainnya, banyak melahirkan tokoh-tokoh besar yang juga memiliki jasa yang besar terhadap upaya mengisi dinamika kemerdekaan. Beberapa tokoh tersebut diantaranya ialah M. Natsir, Isa Anshari, Sjafrudin Prawiranegara, Boerhanoeddin Harahap, Mohammad Roem, dan banyak lainnya yang tercatat memiliki jasa-jasa penting dalam buku sejarah resmi republik.

M. Natsir, sebagai sosok penting dalam pemerintahan parlementer Indonesia (Perdana Menteri pertama, Kabinet Natsir), pada dasarnya memiliki hubungan 
spesial dengan presiden Soekarno, penunjukkannya sebagai Perdana Menteri merupakan tanda bahwa Soekarno menaruh simpati khusus kepada Natsir. Saat wartawan harian Merdeka bertanya kepada Soekarno tentang siapa yang akan menjadi Perdana Menteri dalam negara kesatuan yang baru berdiri, Soekarno dengan mantap menjawab "Ya siapa lagi kalau bukan Natsir dari Masyumi, mereka punya konsepsi untuk menyelamatkan Republik melalui konstitusi" (Natsir, 2014: 22). Walau tanpa dukungan PNI, Soekarno takjub pada jasa besar Natsir dalam proses pengembalian Indonesia menjadi kesatuan yang dilakukan dengan bermartabat dan menyenangkan. Sampai kemudian, hubungan keduanya memburuk pasca perbedaan pandangan dalam sistem ketatanegaraan.

Berbicara tentang pandangannya mengenai Pancasila, dalam pidatonya berjudul "Sumbangan Islam bagi Perdamaian Dunia" yang disampaikan di Karachi, Pakistan, 9 April 1952, disebutkan bahwa Natsir berujar:

"Pakistan adalah negara Islam. Hal itu pasti, baik oleh kenyataan penduduknya maupun oleh gerak-gerik haluan negaranya. Dan saya katakana Indonesia juga negara Islam, oleh kenyataan bahwa Islam diakui sebagai agama dan panutan jiwa bangsa Indonesia, meskipun tidak disebutkan dalam konstitusi bahwa Islam itu adalah agama negara. Indonesia tidak memisahkan agama dari (masalah) kenegaraan. Dengan tegas Indonesia menyatakan percaya kepada Tuhan yang Maha Esa jadi tiang pertama dari Pancasila, kaidah yang lima, yang dianut sebagai dasar ruhani, dasar akhlak dan Susila oleh negara dan bangsa Indonesia (Natsir, 2014: 29-30)"

Setahun berselang, Natsir masih konsisten dengan pendapatnya. Dalam majalah Hikmah edisi 29 Mei 1954, Natsir menulis tentang "Apakah Pancasila Bertentangan dengan Ajaran Al-Quran?". Natsir berhusnuzon kepada para perumus Pancasila pada sidang BPUPK dan PPKI, yang sebagian besar beragama Islam, pastilah tidak akan membenarkan suatu rumusan yang bertentangan dengan Islam. maka dari itu, Natsir mempertegas pemikirannya dengan memberikan pertanyaanpertanyaan yang menarik, yakni:

“Bagaimana mungkin Al-Quran yang memancarkan tauhid, dapat bertentangan dengan ide Ketuhanan yang Maha Esa?; bagaimana mungkin Al-Quran yang ajaran-ajarannya penuh dengan kewajiban menegakkan 'adalah ijtima'iyah bisa bertentang dengan keadilan sosial?; bagaimana mungkin Al-Quran yang justru memberantas sistem feudal dan pemerintahan dictator, dapat bertentangan dengan apa yang dinamakan kedaulatan rakyat?; bagaimana mungkin Al-Quran yang menegakkan istilah Islau Bainan-nas (Damai antara manusia) sebagai dasar pokok yang harus ditegakkan umat islam, dapat bertentangan dengan peri kemanusiaan?; bagaimana mungkin Al-Quran yang mengakui adanya bangsa-bangsa dapat dikatakan bertentangan dengan kebangsaan?"

Inti dari pemikiran tersebut ialah, Natsir yakin bahwa Pancasila akan subur jika berada dibawah naungan Al-Quran. Dan Pancasila akan menjadi lumpuh ketika 
pengamalan sila pertama yakni "Ketuhanan yang Maha Esa" dijalankan dengan skeptis oleh orang-orang yang menganggap agama sebagai produk usang. Sayangnya, selang tiga tahun, keretakan hubungan Natsir dan Soekarno memasuki jilid ke II, dan berdampak kepada pandangan Natsir terhadap Pancasila, dimana perubahan pemikiran tersebut tertuang dalam pidato monumentalnya di Majelis Konstituante dengan judul "Islam sebagai Dasar Negara”.

Perubahan tersebut berangkat dari pidato Soekarno pada rapat Gerakan Pembela Pancasila di Istana Negara tanggal 17 Juni 1954, Presiden Soekarno memberikan pidato yang mengesankan bahwa sila Ketuhanan yang Maha Esa merupakan ciptaan manusia, dan oleh sebab itu bukan merupakan sistem agama Islam. Dalam pidato tersebut, lebih jelasnya Soekarno berujar sebagai berikut:

"dulu, tatkala manusia hidup di alam rimba... ya di bawah pohon dan guagua, dia mengira bahwa Tuhan adalah berupa pohon, petir, atau sungai. Dulu, tatkala manusia hidup di alam peternakan, dia mengira bahwa Tuhan berupa binatang. Sampai sekarang masih ada sisa-sisa bangsa yang menyembah kepada binatang. Dulu, tatkala manusia hidup di taraf agrarian, terutama sekali dulu, dia pun mempunyai ciptaan lain daripada Tuhan itu. Dan tatkala manusia masuk di dalam alam industrialisme, banyak yang sudah tidak mengakui kepada Tuhan lagi... (Natsir, 2014: 34-35)"

Menyikapi pidato tersebut, Natsir sampai pada kesimpulan bahwa bangsa Indonesia, yang merupakan negeri Islam terbesar di dunia, akan sangat berbahaya jika tetap menggunakan Pancasila, yang merupakan sistem sekuler sebagai dasar negara. Dengan dasar negara Pancasila, bangsa Indonesia bagai "lompat dari bumi tempat berpijak, ke ruang hampa focum tak berhawa."

Selain Natsir, adapula beberapa tokoh yang mengemukakan pentingnya "pengaktifan" nya kembali Piagam Jakarta, diantaranya ialah A. Kahar Mudzakkir, Kasman Singodimedjo, dan M. Isa Anshari. A. Kahar Mudzakkir dalam sidang majelis konstituante sendiri tidak panjang lebar menjelaskan secara teoritis (terkait pentingnya Islam sebagai dasar negara), namun lebih kepada paparan historis periodisasi perumusan Pancasila dimana auntentisitas beliau teruji karena beliau merupakan saksi sejarah yang juga tergabung dalam Panitia Sembilan. Hingga di akhir pidato, Mudzakkir memaparkan pendapat yang cukup emosional, yakni:

“Pancasila Piagam Jakarta sudah membuahkan suatu hasil lagi, yaitu bahwa dasar undang-undang pokok pendidikan juga diambil dari agama dan kebudayaan. Saudara ketua, akan tetapi apa lacur pada tanggal 18 Agustus 1945? Semua prinsip-prinsip yang baik dan luhur itu oleh PPK telah diubah, dicoret-coret dan dihapuskan dari mukadimah dan UUD. Itulah sebabnya ada orang yang mengatakan bahwa Pancasila itu dikebiri. Kalau saya tidak mengatakan demikian, akan tetapi Pancasila itu sudah dirusak! Sebab prinsipprinsip yang mendatangkan moral yang luhur dengan adanya Pancasila piagam Jakarta itu telah hilang dari wujud Pancasila, yang tadinya merupakan agreement itu telah dicederai dengan sengaja. Itu berarti pula 
bahwa perjanjian telah dibatalkan dengan sengaja. Itu berarti pula bahwa perjanjian itu telah dibatalkan dengan kehendak "eenzijdig". Saya katakana atas kehendak satu pihak, yaitu pihak kebangsaan! (Orsan, 2017: 16-17)"

Pernyataan Kahar Mudzakkir tersebut jelas menyulut konflik dikotomis antara dua kelompok yang sejatinya memiliki jasa besar dalam perumusan dasar negara. Yakni kelompok kebangsaan dan kelompok Islam. Hal tersebut semakin runyam, karena peran serta golongan komunis di konstituante, -yang sebelumnya di sidang PPKI tidak disertakan karena masih diembargo oleh Jepang- membuat riakriak konflik semakin memanas dengan memunculkan ide baru kebebasan beragama. Melanjutkan pidatonya, Mudzakkir kemudian berujar:

"maka dengan ini, tegas saya katakan bahwa jika orang berbicara tentang pengkhianatan terhadap sesuatu perjanjian yang disebut "Gentlemen Agreement", maka pihak yang mengkhianati bukanlah pihak kami, pihak islam, akan tetapi, pihak yang merubah itulah, yakni yang menghapuskan rumusan-rumusan esensial mengenai islam itu (Orsan, 2017: 17)"

Selanjutnya, Kasman Singodimedjo, yang juga menjadi tokoh sentral dalam proses perumusan Pancasila, berupaya mendinginkan suasana dengan wacana "memperkenalkan Islam, karena tak kenal, maka tak cinta". Beberapa poin sebagai upaya marketing Kasman terhadap pengesahan Islam sebagai dasar negara dengan mengesahkan ulang piagam Jakarta, ialah sebagai berikut:

1. Islam adalah universal dari Allah;

2. Bagaimana anggapan agama Islam terhadap intellect atau kecerdasan pikiran;

3. Islam mewajibkan demokrasi berdasarkan musyawarah yang mendudukkan kebenaran dan hak;

4. Islam mewajibkan pemimpin rakyat, pemimpin negara dan pemimpin pemerintahan penuh bertanggung jawab kepada rakyat dan kepada Tuhan;

5. Islam menegakkan kemerdekaan lahir dan batin, menolak penjajahan, penindasan atau eksploitasi manusia atas manusia dalam bentuk apapun;

6. Islam memberantas kemelaratan dan menegakkan kemakmuran lahir dan batin atas dasar hidup keragaman antara golongan dan kelas;

7. Islam mewajibkan menunaikan fardhu kifayah di samping menunaikan fardhu 'ain, sehingga tidak boleh ada egoism yang tamak atau bakhil; kekayaan (milik) perseorangan tidak terlepas dari fungsi sosial sehingga rizki dapat merata; dan

8. Islam memberi penilaian yang sama antara kaum wanita dan kaum pria dengan tidak mengurangi kenyataan, bahwa perbedaan sifat dan bakat antara kaum wanita dan kaum pria membawa pula pembagian tugas dan lapangan pekerjaan bagi masing-masing jenis kaum itu (Orsan, 2017: 24-61).

Perdebatan mengerucut pada dialektika antara Kasman, yang kemudian dilanjutkan oleh M. Isa Anshari tentang mana yang lebih relevan antara pendapat keislaman Kasman, serta klaim dari Njoto (Tokoh LEKRA, Wakil CC PKI) tentang 
dasar Pancasila yang sudah didukung oleh 5 golongan yaitu golongan nasionalis, protestan, katholik, komunis, dan sebagian golongan Islam.

Sayangnya, perdebatan sengit antara kelompok nasionalis-sekuler dengan kelompok nasionalis-islamis mengalami deadlock, walhasil, kondisi tersebut disegel langsung oleh dekrit presiden tertanggal 5 Juli 1959. Dekrit tersebut merupakan penanda bahwa majelis konstituante resmi dibubarkan, dan Undang-undang Dasar 1945 dinyatakan berlaku kembali, dimana UUD 1945, mengandung dasar-dasar Pancasila yang ditetapkan dalam sidang PPKI, dimana sila pertama ialah "ketuhanan yang maha Esa". Sebagai solusi dari kekisruhan tersebut, konsiderans Dekrit Presiden kemudian memasukkan kalimat "Kami berkeyakinan bahwa Piagam Jakarta tertanggal 22 Juni 1945 menjiwai Undang-undang Dasar 1945 dan adalah merupakan suatu rangkaian kesatuan dengan konstitusi tersebut".

Di sisi lain, debat konstituante tidak serta merta menandakan debat kusir antar anggota dewan konstituante, ataupun kekalahan kelompok Islamis, karena seiring dengan kembalinya kepada UUD 1945, pada akhirnya juga menihilkan upaya golongan komunis yang memiliki gagasan hendak memeras Pancasila menjadi Ekasila, yakni gotong royong tanpa Ketuhanan yang Maha Esa, atau mengganti Ketuhanan yang Maha Esa dengan sila kebebasan beragama yang juga menempatkan ateisme sebagai kebebasan beragama (Osman, 2017: 21). Namun perlu dipahami, bahwa pembubaran konstituante, menurut hemat penulis, bukan menandakan bahwa konstituante gagal membentuk Undang-undang baru. konstituante pada dasarnya belum menyelesaikan pekerjaannya. Pekerjaannya digunting, oleh Dekrit yang dikeluarkan Soekarno, dengan dukungan penuh militer.

\section{Islamisme Indonesia Dewasa Ini}

Berlangsungnya gerakan aksi massa 411 dan 212, ditambah menjamurnya gerakan-gerakan hijrah di kalangan pemuda dimana mubaligh-mubaligh nya berasal dari luar organisasi Islam mainstream seperti halnya NU dan Muhammadiyah, memperlihatkan bahwa geliat keberagamaan khususnya Islam berangsur-angsur bangkit sebagai kekuatan baru. Tak sampai disitu, pilpres 2019 bahkan memperlihatkan bahwa Islam kemudian menjadi "rebutan" masing-masing Calon Presiden untuk mencitrakan diri menjadi yang paling "islami" walaupun baru pada tataran formal (Adiwilaga, 2019).

Kondisi tersebut berdampingan dengan Hasrat yang besar dari kelompok Islam tertentu untuk menjalankan misi "pemurnian". Pesatnya gerakan tarbiyah, ditambah dengan kecerdikan kelompok-kelompok Islam tertentu seperti Hizbut Tahrir dalam memanfaatkan sosial-media, ditambah dengan strategi dakwah yang cerdik karena berusaha melebur pada keseharian pemuda saat ini seperti halnya Felix Siauw yang di awal dakwahnya menyuarakan lika liku asrama melalui kacamata Syariah, pada prosesnya kemudian semakin memperkokoh konstruksi 
kader kelompok Islam ini yang saat ini menjadi oposisi pemerintah terpilih, dimana Nahdhatul Ulama bersanding mesra dengan pemerintah terpilih tersebut.

Menguatnya wacana Negara Islam dan formalisasi Syariat Islam di Indonesia merupakan suatu fenomena sosio-politik-keagamaan yang -dalam Bahasa Asroni, menggembirakan sekaligus problematis. "Menggembirakan" lantaran menguatnya wacana negara Islam dan formalisasi Syariat Islam menandakan bahwa sebagian umat Islam Indonesia sedang mengalami kegairahan dalam beragama (Islam). Problematis dikarenakan wacana negara Islam dan formalisasi Syariat Islam akan mengancam keutuhan Negara Kesatuan Republik Indonesia (NKRI) yang berideologi Pancasila dan berdasar UUD 1945 (Asroni, 2011: 358). Kegagalan pemerintah dalam mengelola negara dipandang oleh sebagian umat Islam sebagai kesalahan dalam memilih bentuk dan ideologi negara. Bagi sebagian umat Islam Negara Kesatuan Republik Indonesia sudah seharusnya diganti dengan pemerintahan Khilafah Islamiyah dengan mengganti pancasila dengan syariat Islam sebagai ideologi (Nashir, 2013).

Kelompok Islamisme yang cenderung bermatemorfosa menjadi kelompok populis ini, bahkan menganggap bahwa pemerintah sah saat ini adalah pemerintah thogut. Belum puas, kelompok ini menganggap bahwa segala huru-hara kehidupan bernegara seperti halnya korupsi, kesenjangan sosial, dekadensi moral, bahkan dampak pembangunan, semua berawal dari kesalahan pemerintahan "kafir" dalam menjalankan roda pemerintahannya. Maka dari itu solusi dari segala kecarut marutan ini ialah penerapan khilafah secara menyeluruh, mengingat hukum Allah yang semua terangkum dalam Islam, merupakan panduan utuh kemanusiaan yang dapat menjawab segala permasalahan duniawi plus mendapat ganjaran surgawi yang kekal abadi.

Sayangnya, kritik-kritik tersebut tidak berbanding terbalik dengan komposisi dari formula penangkal yang ditawarkan. Nubowo dalam tulisannya, "Islam dan Pancasila di Era Reformasi: Sebuah Reorientasi Aksi", memaparkan bahwa sejatinya, Pada level praktis, tidak ada konsensus (ijma') di kalangan para pengusung ideologi Syariah tentang formulasi syariah yang akan dijadikan sebagai hukum positif. Masing-masing penegak syariat Islam mempunyai formulasi syariah sendiri. Pandangan keagamaan dan madhab hukum di kalangan umat Islam juga majemuk. Di kalangan ahlus sunah wal jamaah sendiri terdapat empat madzhab fikih yang popular (Hanafi, Hambali, Maliki dan Syafii). Kelompok islamisme kontemporer juga sejatinya tidak memiliki rujukan sejarah yang jelas tentang Kekhalifahan mana yang ingin ditiru. Sebab secara umum kekhilafahan Islam tidak bisa disebut sukses. Hanya hingga zaman Umar bin Khattab saja yang mengalami masa damai dan sukses besar. Tapi setelah masa itu sulit dikatakan sebagai era yang sukses. Khilafah Ottoman misalnya, pada akhirnya takluk kepada inggris sampai kemudian diselamatkan gerakan nasionalisme (Shihab, 2019: 115).

Armanjani kemudian berusaha memeras bentuk gerakan-gerakan tersebut menjadi beberapa simpulan. Menurutnya, negara yang berdasarkan syariat memiliki 
bangun ideologi sebagai berikut: (1) Syariat harus mengatur seluruh aspek kehidupan di negara-negara muslim; (2) setiap pemerintahan harus mampu mewujudkan muslim yang paripurna, yaitu muslim yang patuh menjalankan rukum Islam dan memiliki keyakinan yang sesuai dengan rukun iman; (3) Pemerintahan dapat dicapai melalui mekanisme demokratis, atau melalui sistem monarki yang dipimpin oleh amir yang dianggap sebagai bayang-bayang Tuhan di muka bumi; (4) Pemerintah berdasarkan Islam harus memberi dukungan finansial dan politik terhadap sekolah dan perguruan tinggi Islam, di luar sistem pendidikan Islam dibumihanguskan; (5) Pemerintahan harus menjamin terjaganya basis moral dalam kehidupan sehari-hari, seperti halnya pakaian, pergaulan, minuman, kebudayaan, sistem ekonomi, dan lain sebagainya (Armanjani, 2012: 21-22).

Akhir pembahasan, maka dapat disimpulkan bahwa sejatinya, Piagam Jakarta yang lahir sebagai upaya kelompok Islam pra-kemerdekaan untuk melakukan formalisasi syariat Islam dengan mimpi mewujudkan Islam rahmatan lil alamin era Piagam Madinah, sama sekali tidak memiliki benang lurus dengan perjuangan islamisme kontemporer. Piagam Jakarta penulis nilai hanya dijadikan acuan atau pemantik historis dalam mengobarkan semangat atau gairah keislaman dewasa ini. Penulis berani menegaskan bahwa tak ada benang lurus yang menghubungkan piagam Jakarta dengan gerakan islamisme kontemporer, karena diferensiasi keduanya sangat lah jauh, khususnya dari segi kualitas dialektis serta ketiadaan formula yang "satu" dan tegas terkait bentuk Syariah seperti apa yang dikehendaki dalam membangun NKRI bersyariah.

\section{Kesimpulan}

Anwar Sadat dalam tulisannya, "Memotret Geliat Hukum Islam di Indonesia: Sebuah Pertarungan Konstitusional", menjelaskan bahwa hal-hal pokok yang mutlak perlu dilindungi oleh syari'at Islam menurut al-Syatibi ada lima, yakni agama, jiwa, keturunan (kelangsungan generasi), harta dan akal. Menurut al-Syatibi, perlindungan terhadap kelima hal ini mutlak (dlaruriyyat), karena kelima hal ini diperlukan untuk tegaknya kemashlahatan agama dan dunia. Dlaruriyat dalam pandangan al-Syatibi adalah sesuatu yang bila tidak dijalankan maka akan timbul kekacauan dan kesulitan yang nyata. Perlindungan terhadap agama, bagi umat Islam mengandung pengertian bahwa umat mesti dilindungi dalam menjalankan rukun atau kewajiban agamanya mulai dari syahadat, shalat, zakat, puasa sampai dengan haji. Perlindungan terhadap agama juga mengandung pengertian agar agama dijaga kelestariannya dan dilindungi dari hal-hal akan merusaknya. Demikian pula perlindungan terhadap jiwa, keturunan, harta dan akal. Adapun menutup aurat atau hal-hal yang berkaitan dengan kesopanan dan keluhuran budi pekerti masuk kategori tahsiniyat.

Oleh karena itu jika yang diformalkan adalah prinsip-prinsip umum syari'at Islam yang bisa membawa kemaslahatan bagi semua golongan maka formalisasi syari'at Islam tidak akan menimbulkan masalah. Tapi jika umat Islam mau 
memformalkan hukum pidana Islam peninggalan masa lalu maka mereka harus berani melakukan reformasi dan reinterpretasi terhadap bagian-bagian yang sudah tidak relevan dengan perkembangan masa kini agar bisa diterima dan kiranya bisa membawa maslahat bagi semua orang. Hukuman rajam (dilempari batu sampai mati) dan hukuman potong tangan tidak mungkin bisa diundangkan di Indonesia. Pun halnya hukum cambuk telah dilaksanakan di Aceh, namun aturan tersebut mengundang kontroversi tidak hanya di Indonesia, bahkan di berbagai belahan bumi yang lain.

Gerakan Islamisme kontemporer tak akan bergerak kemana-mana jika yang terus diperbincangkannya adalah hukum menggunakan celana "cingkrang", haram mengucapkan perayaan hari raya agama lain, pun halnya haram perayaan dalam Islam sendiri (baca: Maulid Nabi). Gerakan Islamisme kontemporer perlu mampu meyakinkan masyarakat terkait konsepsi syariahnya. Paradigma Syariah yang disuarakan perlu bergeser dari aturan formal tentang ranah privat yang terkesan intimidatif, menjadi aturan-aturan yang menghadirkan kemaslahatan bersama seperti penghapusan tindak korupsi, kemajuan pendidikan, kebangkitan ekonomi umat dan lain sebagainya. Gerakan islamisme kontemporer perlu memberikan pandangan, bahwa ketika negara memikirkan warga negaranya, memberikan perlindungan, mencerdaskan bangsa, dan menghindari berbagai tindakan yang merusak rakyatnya, itu semua sudah sejalan dengan Islam.

\section{Referensi}

Adiwilaga, Rendy. (2020). Pasang Surut Pancasila: Sebuah Pengantar tentang Sejarah dan Pemaknaan Pancasila. Bandung: Inteligensia Media.

Adiwilaga, Rendy. (2019). Quo Vadis Islamic Populism? An Electoral Strategy. The Central European Journal of International and Security Studies (CEJISS). 13(4). 432453.

Adiwilaga, Rendy. (2018). Quo Vadis Khilafatisme: Sebuah Keniscayaan atau Ancaman dalam Diskursus Ideologi Republikan Pancasilais. Jurnal Waskita. 2(1). 72-89.

Adiwilaga, Rendy. (2017). Gerakan Islam Politik dan Proyek Historis Penegakan Islamisme di Indonesia. Jurnal Wacana Politik, 2(1). 1-9. doi: 10.24198/jwp.v2i1.11373

Anshari, Endang Saifuddin. (1997). Piagam Jakarta 22 Juni 1945: Sebuah Konsensus Nasional tentang Dasar Negara Republik Indonesia (1945-1949). Jakarta: Gema Insani Press.

Armanjani, Jon. (2012). Modern Islamist Movements: History, Religion, and Politics. United Kingdom: Willey-Blackwell. 
Asroni, Ahmad. (2011). Pemikiran Ahmad Syafii Maarif tentang Negara dan Syariat Islam di Indonesia. Millah. 9 (1). 358.

Firdausi, Fadrik Aziz. "Bagaimana Abu Bakar Al-Baghdadi Mendirikan ISIS" pada laman: https://tirto.id/bagaimana-abu-bakar-al-baghdadi-mendirikan-isiscHov.

Hatta, Mohammad. (1979). Mohammad Hatta Memoir. Jakarta: Tinta Mas.

Hikmawan, M. D. (2017). Pluralisme Demokrasi Politik di Indonesia. Journal of Governance, 2(2), 223-247. https://doi.org/http://dx.doi.org/10.31506/jog.v2i2.2678

Isnaeni, Hendri F. "Mengapa NU Keluar dari Masyumi?" Diakses pada laman https://historia.id/politik/articles/mengapa-nu-keluar-dari-masyumi-PzMm8

Latif, Yudi. (2018). Wawasan Pancasila: Bintang Penuntun untuk Pembudayaan. Bandung: Mizan.

Latif, Yudi. (2012). Negara Paripurna: Historisitas, Rasionalitas, dan Aktualisasi Pancasila. Jakarta: Gramedia Pustaka Utama.

Matanasi, Petrik, "Ki Bagus Hadikusumo, Pendukung Keras Piagam Jakarta". Diakses di https://tirto.id/cq7q.

Nashir, Haedar. (2013). Islam Syariat; Reproduksi Salafiyah Ideologis di Indonesia. Bandung: Mizan dan Maarif Institute.

Nubowo, Andar. (2015). Islam dan Pancasila di Era Reformasi: Sebuah Reorientasi Aksi. Jurnal Keamanan Nasional. 1(1).

Sadat, Anwar. (2014). Memotret Geliat Hukum Islam di Indonesia: Sebuah Pertarungan Konstitusional. Jurnal PILAR. 2 (2). 78-101.

Shihab, Alwi. Dkk. (2019). Islam dan Kebhinekaan. Jakarta: Gramedia Pustaka Utama.

Singodimedjo, Kasman. (1982). Hidup itu Berjuang: Kasman Singodimedjo 75 Tahun. Jakarta: Bulan Bintang. 